\section{National and Cultural Values According to The Perceptions of Third Grade Primary Students*}

\author{
Hüseyin Anılana, Zeynep Kılıç, Zülfiye Melis Demirc,*
}

$\begin{array}{ll}\text { Received: } & \text { 09 January } 2019 \\ \text { Revised: } \quad 31 \text { March } 2019 \\ \text { Accepted: } \quad \text { 16 June } 2019 \\ \text { ISSN: 1307-9298 } \\ \text { Copyright C IEJEE } \\ \text { www.iejee.com }\end{array}$

DOI: $10.26822 /$ iejee.2019553348

\begin{abstract}
One of the lessons that contribute to the education of individuals who have national and cultural values as well as universal values such as tolerant, virtuous, healthy, honesty, responsibility, scientific, love and respect is Life Studies course on primary schools. Life Studies course is one of the courses taught by students in primary schools and the main objective is to provide students with knowledge, skills and value. One of the highlighted values and skills in the 2018 Life Studies Course Curriculum is Recognition of National and Cultural Values (Ministry of National Education, 2018). The aim of this study is to reveal the perceptions of third grade students about their national and cultural values. In this study, the perceptions of third grade students about national and cultural values are examined based on their opinions and drawings. The method was art-based research. 40 students ( 22 female and 18 male) participated in this study, which aimed to reveal the perceptions of third-grade elementary school students on national and cultural values. In order to determine the participants, criterion sampling was used. In this research, which aims to reveal the perceptions of third-year elementary school students on national and cultural values, the findings were presented as two main themes: "Reflection of National and Cultural Values in drawings and written opinion" and "Characteristics of National and Cultural Values" and sub-themes under each theme. While some of the students draw an object or figure as a national and cultural value, some students drew more than one figure or object related to different national and cultural values in the drawings. Some students emphasized different national and cultural value in their written opinions and paintings.
\end{abstract}

Keywords: Primary School, Art-Based Research, Drawing, National and Cultural Values, Turkey

\section{Introduction}

While developments in science and technology provide the necessary opportunities for individuals to improve their lives, on the other hand it also confronted with problems such as environmental pollution, global warming, violence and terror. Individuals must have some properties to overcome with these problems and to be able to live in tolerance and respect with other individuals in the complex society. These properties appear as values. The value can be determined as "the whole of the material and spiritual elements that cover the social, cultural, economic and scientific values of a nation" (TDK, 2012) and "the whole of the beliefs that contain the most basic characteristics that differentiate human from other living things" (Ulusoy \& Dilmaç, 2012, p. 16).

Culture is a collection of formal and peculiar values of all societies and communities that exist in the world (Paşaoğlu, 2009, p.144). Values determine the common behavior patterns that must be followed in the society by creating social solidarity (Yaman, Taflan \& Çolak, 2009, p.107). In this respect, cultural values affect the culture and culture affecT cultural values. The change or differentiation in the common behavior of the society is reflected in the culture of the society and the cultural values of the society (Kasa, 2015). With regard to the third learning domain "Culture and the arts" there is an expectation that children and young people will have opportunities for creative expression in a wide variety of art forms and cultural experiences to foster knowledge and skills in the area of the creative arts and culture, personal and communal identity, and awareness of and respect for diversity.

Values education is an important process that ensures the continuity of societies by enabling individuals' internalization of values. By means of values education, individuals are able to transfer their culture to future generations (Bayır-Gürdoğan, 2019, p.403). Values bring a sense of security, meaningfulness, purpose and a sense of future into the individual's participation in social life. Values are used to describe societies and individuals, to monitor the change over time, and to explain the motivational basis of attitudes and behaviors. When values are used for qualification and discovery among cultures, they represent shared abstract ideas about what is good, what is right or what is desirable. Cultural values serve as the criterion used to explain which behavior individuals have in society, to guide their self-presentation and to defend their own preferences. Some of the social, historical and intellectual values becomes the society's cultural values. Each culture has its own human, society and world understanding and values.

Values education starts informally in the family and continues in formal schools. The values education is carried out through education programs in schools as well as through implicit programs. Nowadays, rapid technological and scientific developments deeply affect societies and especially human relations; The importance given to the acquisition of values through a curriculum to the new generation is increasing. One of the lessons that contribute to the education of individuals who have national and cultural values as well as universal values such as tolerant, virtuous, healthy, honesty, responsibility, scientific, love and respect is Life Studies Course on primary schools. Life Studies course is one of the courses taught by students in primary schools and the main objective is to provide students with knowledge, skills and value. One of the highlighted values and skills in the 2018 Life Studies Course Curriculum is Recognition of National and Cultural Values (Ministry of National Education, 2018. This study is limited with these values.

\footnotetext{
'This research has been presented as an oral presentation at International Congress on Science and Education 2018 (ICSE2018)

a Hüseyin Anılan, Eskişehir Osmangazi University, Eskişehir, Turkey. E-mail: hanilan@ogu.edu.tr

' Zeynep Kılıç, Eskişehir Osmangazi University, Eskişehir, Turkey. E-mail: zeynepk@ogu.edu.tr

${ }^{* * *}$ Corresponding Author: Zülfiye Melis Demir, Eskişehir Osmangazi University, Eskişehir, Turkey. E-mail: zmelisdemir@gmail.com
} 
The aim of this study is to reveal the perceptions of third grade students about their national and cultural values. Art-based research was used as the method in the research and the drawings of the students were used. The drawings that are drawn by children provide researchers with a different sequence of data and an alternative means of perceiving it (Kendrick \& Mckay, 2004, p.110). Thus, it is considered that it is important to reveal the perceptions of students about national and cultural values through art-based research.

\section{Method}

The art-based research content artistic process, forms and applications in scientific field. Art-based research has therefore benefited from creative arts to shape and inform social science research (Sinner, Leggo, Irwin, Gouzouasis \& Grauer, 2006, p. 1226). Art-based research describes an epistemological foundation for human inquiry that utilizes artful ways of understanding and representing the worlds in which research is constructed (Finley, 2008, p.79). The aim in art-based research is to understand and explain the experiences of the researcher and the participants in the research process of the artistic process and the artistic forms (McNiff , 2007, p.40; Mullen, 2003, p.166). It can be suggested that art-based educational research approach possess some applications which help research process sustain more effectively and authentically. The investigation of the process by its nature in a constructive and multidimensional way offers researchers unusual departure points. This case may make the research an authentic, creative and qualified one (Duygu \& Erişti, 2015, p.395). Art-based methodological outcomes are validated not primarily through a triangulation of methods but within what I would describe as ephemeral constructs of validity. Art praxis methodology invites an anti-foundational "validity of transgression that runs counter to the standard foundational validity of correspondence". It has been striking to note how flexible the concept of validity is, and that it is not an unusual practice to determine alternatives to conventional conceptions of validity when altering research paradigms and/or designs (Eisenhart \& Howe, 1992; Lather, 1993, p.675; Cited: Rolling, 2010, p.109). In art-based research, participants present their perceptions of facts or situations in an artistic way (Eisner, 2006, p.11). One of these ways is children's drawing. Children's drawings reflect the thought and emotion in the child's mind, and the symbols and figures used by the child give a hint about the subject (Greig, Taylor \& Mackay, 2007, p.93). Children's drawings have helped them communicate the diverse ways in which they see themselves and others as literate beings across contexts such as home, school, and community (Pirtle \& Maker, 2012, p.146). In this study, the perceptions of third grade students about national and cultural values are examined based on their opinions and drawings.

\section{Participants}

40 students ( 22 female and 18 male) participated in this study, which aimed to reveal the perceptions of third-year elementary school students on national and cultural values. 36 students aged 9 and 4 students aged 8 participated in this study. In order to determine the participants, criterion sampling was used. The basic understanding of criterion sampling is the study of situations that meet a predetermined set of criteria (Yıldırım \& Şimşek, 2011, p. 112). In this study, it was taken as the criteria that students should be studying third grade in primary schools in different socio-economic levels. The reason for the selection of the third grade students in the study; students have the Life Studies course. "Recognition of National and Cultural Values" is including as a life skill in the Life Science Course Curriculum.

\section{Data Collection}

The data of the research conducted in order to reveal the perceptions of the national and cultural values of the third grade elementary school students were gathered in March 2018. In the process of data collection, firstly, these questions were asked to students: "What do you understand when it is said that national and cultural values? What are you thinking about?" and than wanted to draw about national and cultural values. In art-based studies, children are asked to draw a case or situation in a verbal or written way (Mair \& Kierans, 2007). In this research it was asked to the participants "Can you tell us the drawing you made? What did you draw? and What are your thoughts on national and cultural values?".

\section{Data Analysis}

Descriptive analysis technique was used to analyze the data obtained from the study. In the descriptive analysis, themes are determined first, the data are summarized and interpreted within the scope of these themes and direct quotations from the interviews or observations are included. The reason for direct quotations is to reflect the views of the interviewed or observed people in a striking manner (Yıldııım \& Şimşek, 2011). In this way, firstly the drawings that the students have drawn are examined and a checklist has been created to determine what is in the drawings. Checklist is as follows:

Table 1. Checklist For Researcher

\begin{tabular}{l} 
Criterions \\
$\begin{array}{l}\text { Picture/Student's } \\
\text { Interviews/Number } \\
\text { of Research/ }\end{array}$ \\
picture drawn by the students? \\
\hline $\begin{array}{l}\text { What are the units of the stu- } \\
\text { dents' interviews? }\end{array}$ \\
\hline Is the discourse of the students \\
interviewed with the units in \\
the picture consistent with \\
each other? \\
\hline Are the themes and the themes \\
created by the researchers con- \\
sistent with each other?
\end{tabular}

According to the checklist above, the researchers completed the students' drawings and the students' interviews. Then, a form was formed for the students' written expressions, and descriptive index and research interpretation sections were opened to the forms. Forms and checklists were separately filled by each researcher. Below is a sample checklist.

As shown in Table 2, each researcher separately analyzed the data according to the questions on the checklist and completed checklists for each student and each image for data analysis. For the first question in the checklist, each researcher examined the picture drawn by the student and wrote the elements in the picture to the checklist. For the second question, each researcher filled the checklist taking into account the views of the students. For the third question in the checklist, each researcher examined the consistency of the student's drawing with the picture drawn by the student and decided whether it was consistent. As a final question, each researcher decided what theme would be by taking into consideration the elements of the student's drawing and the student's view. Thus, each researcher completed both the data analysis and the preliminary study for validity and reliability by filling the checklist. 
Table 2. Sample Checklist

\begin{tabular}{|c|c|c|c|}
\hline Criterions & $\begin{array}{l}\text { Number } \\
\text { of picture }\end{array}$ & $\begin{array}{l}\text { Picture/Student's } \\
\text { Interviews/Number of } \\
\text { Research/ }\end{array}$ & Researcher \\
\hline $\begin{array}{l}\text { Which units are } \\
\text { included in the } \\
\text { picture drawn } \\
\text { by the students? }\end{array}$ & 39 & & $\begin{array}{l}\text { Coffee } \\
\text { cup, coffee } \\
\text { plate, } \\
\text { sugar, a } \\
\text { small glass } \\
\text { of water } \\
\text { (items next } \\
\text { to Turkish } \\
\text { coffee) }\end{array}$ \\
\hline $\begin{array}{l}\text { What are the } \\
\text { units of the } \\
\text { students' } \\
\text { interviews? }\end{array}$ & 39 & $\begin{array}{l}\text { S39 "I drew our local } \\
\text { drink, coffee." }\end{array}$ & $\begin{array}{l}\text { The } \\
\text { student } \\
\text { stated that } \\
\text { he drew } \\
\text { Turkish } \\
\text { coffee. }\end{array}$ \\
\hline $\begin{array}{l}\text { Is the discourse } \\
\text { of the students } \\
\text { interviewed } \\
\text { with the units } \\
\text { in the picture } \\
\text { consistent with } \\
\text { each other? }\end{array}$ & 39 & & Yes, it is. \\
\hline $\begin{array}{l}\text { Are the themes } \\
\text { and the themes } \\
\text { created by the } \\
\text { researchers } \\
\text { consistent with } \\
\text { each other? }\end{array}$ & 39 & & $\begin{array}{l}\text { Customs of } \\
\text { /Themes }\end{array}$ \\
\hline
\end{tabular}

\section{Validity and Reliability}

In this study, some measures have been taken by the researchers to ensure the validity and reliability. These measures are shown in table 3 below.

Checklists and forms were filled separately by researchers to ensure the reliability and validity of the research. And then the researchers compared the checklists and forms together. In cases where there is a conflict in the checklists and forms, the drawings and written expressions of the students are reviewed again and again. After that, these checklists and forms were presented to two experts (from faculty members specialized in visual arts teaching and values). Two experts and researchers came together to discuss checklists and forms, and experts and researchers have disputed the control list and two units on the form. Relevant drawings and student castings were reviewed and the dispute was resolved, a consensus was reached. The findings were presented without comment and direct quotations were made in the presentation of the findings and the images were used. In addition, student names were coded like S1, S2, S3. Students used more than one national and cultural elements in their drawings. Therefore, symbols and figures in a drawing can be placed under multiple themes.

Table 3. Roads Used to Provide Validity and Reliability in Research

\begin{tabular}{lll}
\hline & \multicolumn{1}{c}{$\begin{array}{l}\text { Obtaining expert opinion } \\
\text { Validity }\end{array}$} & $\begin{array}{l}\text { Direct quote } \\
\text { Support with images }\end{array}$ \\
\cline { 2 - 3 } Validity & $\begin{array}{l}\text { Explanation of data collection tool and } \\
\text { process }\end{array}$ \\
& $\begin{array}{l}\text { Explanation of data analysis process } \\
\text { Validity }\end{array}$ & $\begin{array}{l}\text { Describing the implementation process } \\
\text { of the participants }\end{array}$ \\
& $\begin{array}{l}\text { Purpose sampling (Being a student of } \\
\text { third grade in primary school and attend- } \\
\text { ing the Life Studies Course) }\end{array}$ \\
\hline \multirow{3}{*}{ Reliability } & $\begin{array}{l}\text { Internal } \\
\text { Reliability }\end{array}$ & \begin{tabular}{l} 
Presenting the findings without comment \\
\cline { 2 - 3 }
\end{tabular} \\
\cline { 2 - 3 } & $\begin{array}{l}\text { External } \\
\text { Reliability }\end{array}$ & $\begin{array}{l}\text { Checking the consistency between data } \\
\text { Checklist }\end{array}$ \\
\hline
\end{tabular}

\section{Findings}

In this research, which aims to reveal the perceptions of third-year elementary school students on national and cultural values, the findings were presented as two main themes: "Reflection of National and Cultural Values in drawings and written opinion" and "Characteristics of National and Cultural Values" and sub-themes under each theme. The themes obtained are shown in figure 1.

Symbols, images, figures, objects related to national and cultural values in the students' drawings were in the theme of "The Reflections of National and Cultural Values in Drawings and Written Opinion, and the sub-themes were "Customs, Arts, Language and Sports, Fatherland, History and Religion". The theme "Characteristics of national and cultural values, is divided into "Inheritance, belonging, promotion and lifestyle" categories. Figure 2 shows the elements that the students draw on the custom sub-theme.

In the drawings of students within the scope of national and cultural values, they focused on food culture, clothing, dowry and wedding. Students drew "ayran, Turkish coffee, tea" as a drink, and "Turkish pizza, baklava, künefe, tulumba, pita, rice" as a food for the sub-theme of Food Culture. Student 15 "I draw the coffee because its our regional drink.". Students' drawings are as follows.

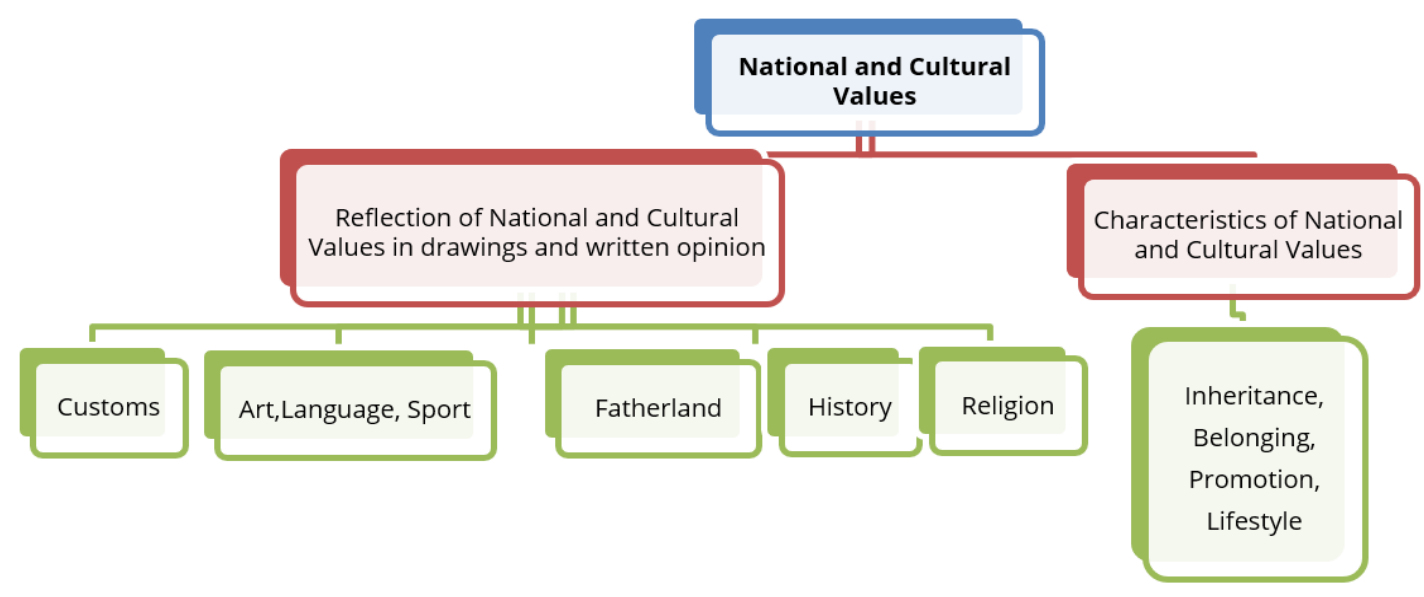

Figure 1. National and cultural values of primary school third-grade students 


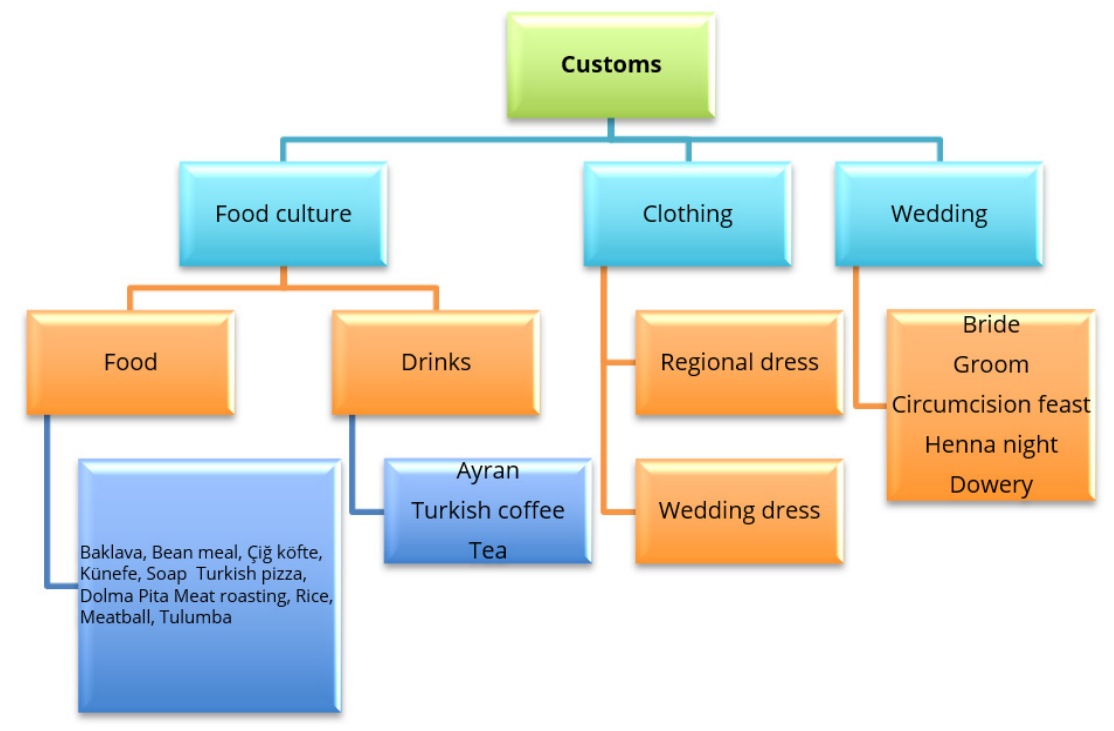

Figure 2. Customs in the drawings of third-grade students

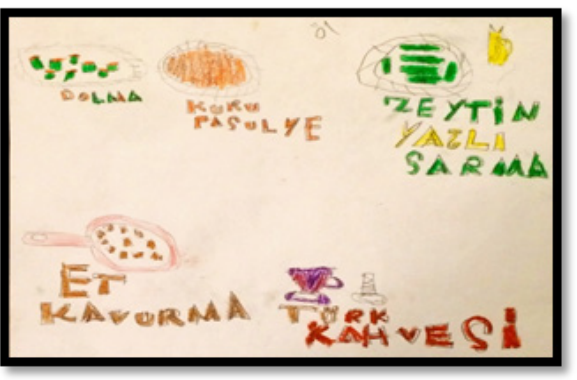

Drawing 1. Student 1

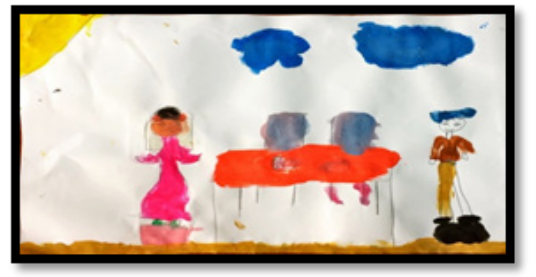

Drawing 3. Student 28

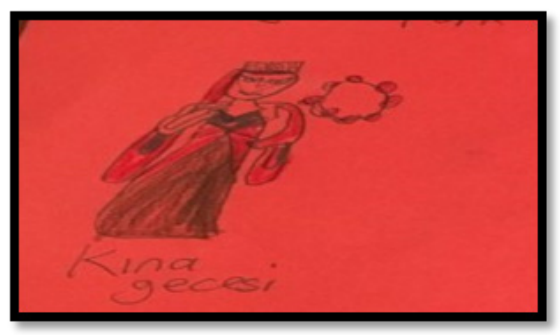

Drawing 5. Student 20

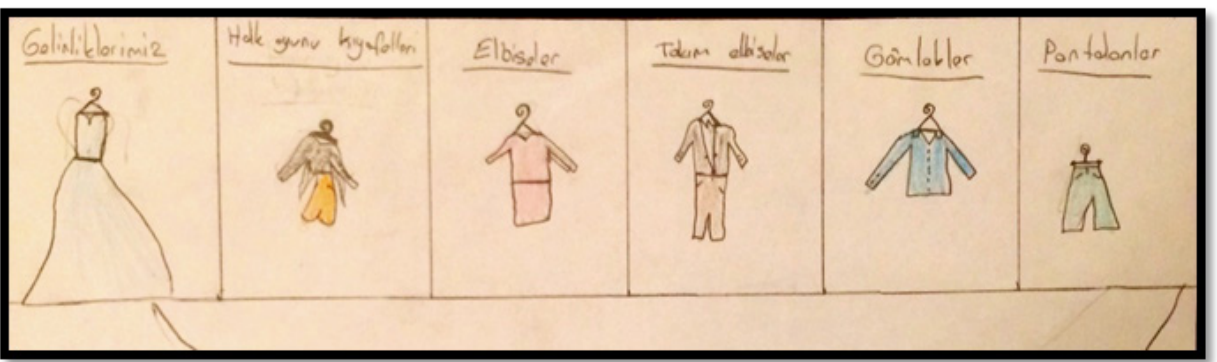

Drawing 6. Student 13

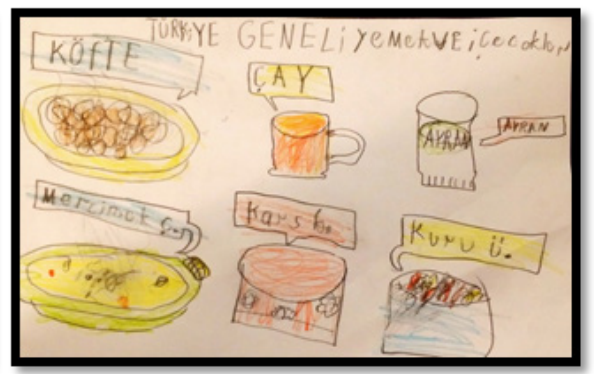

Drawing 2. Student 7

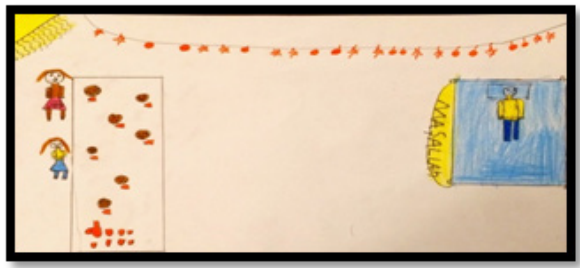

Drawing 2. Student 16

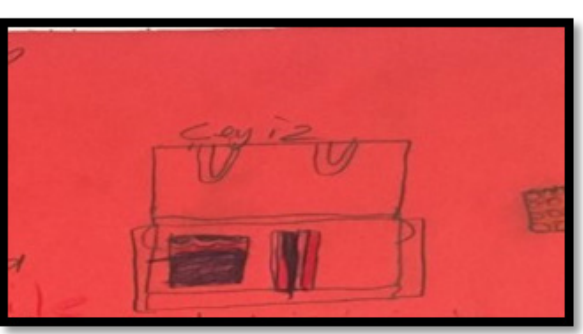




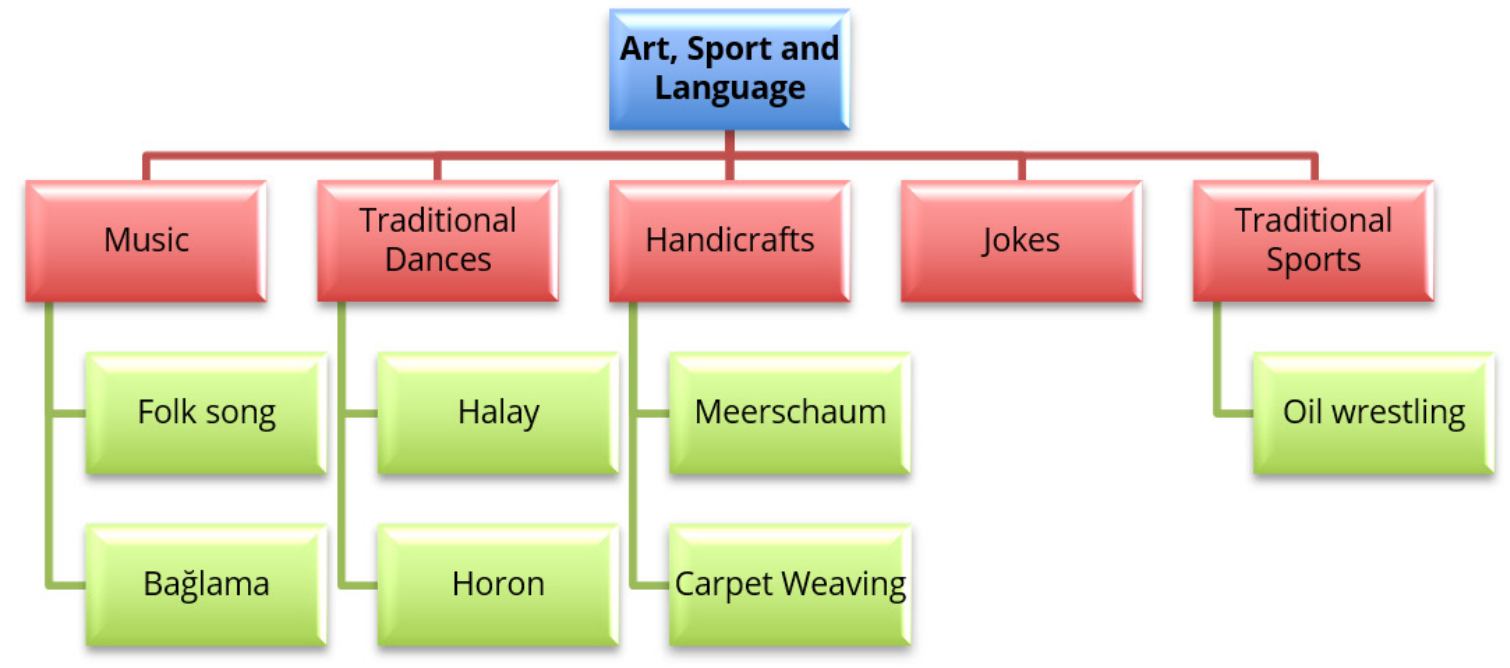

Figure 3. Art, sports and language in the drawings of third grade students

It was seen that students drew regional clothes and wedding dresses as a national and cultural values. In addition, students have reflected the dowry and wedding related items in their drawing as customs. The drawings of students are as follows.

S28 said that "I drew wedding, bride and groom. They came to my mind when I thought national and cultural values". S13 "I drew wedding dresses and regional dresses. S13' drawing is as follow.

The elements that the students drew as the national and cultural values in the theme of art, sports and language are shown in Figure 3. In the drawings made by students, the elements related to national and cultural values are divided into sub-categories in the form of music, traditional dances, handicrafts, jokes and traditional sports in the theme of art, sports and language.

S19 "I draw Meerschaum and Carpet weaving" as Turkish traditions or values. And S20, "When I said national and cultural values, it comes to my mind our jokes, folk carpet weaving" so they have emphasized our music, handicrafts and language as national and cultural values. Again from S31 I draw halay as a national and cultural value because each region has its own dance. For example, they play horon." The drawings of the students are as follows.

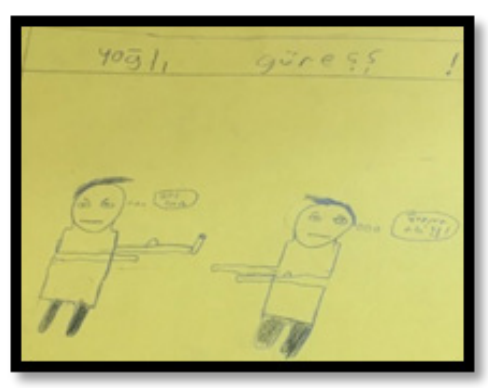

Drawing 7. Student 17

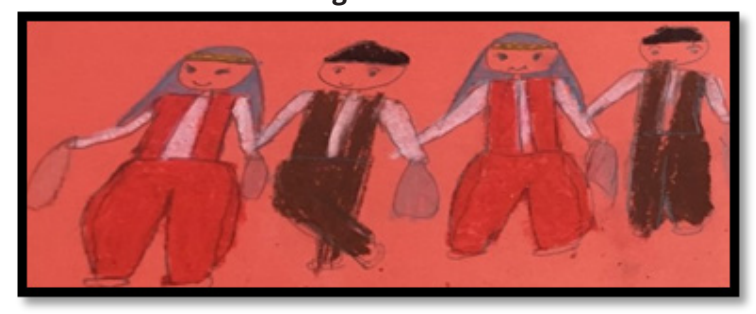

Drawing 8. Student 31

The elements that the students draw in the theme of religion as national and cultural values are divided into sub-categories as religious holidays, Mevlana and place of worship. The items drawn by the students are shown in Figure 4.

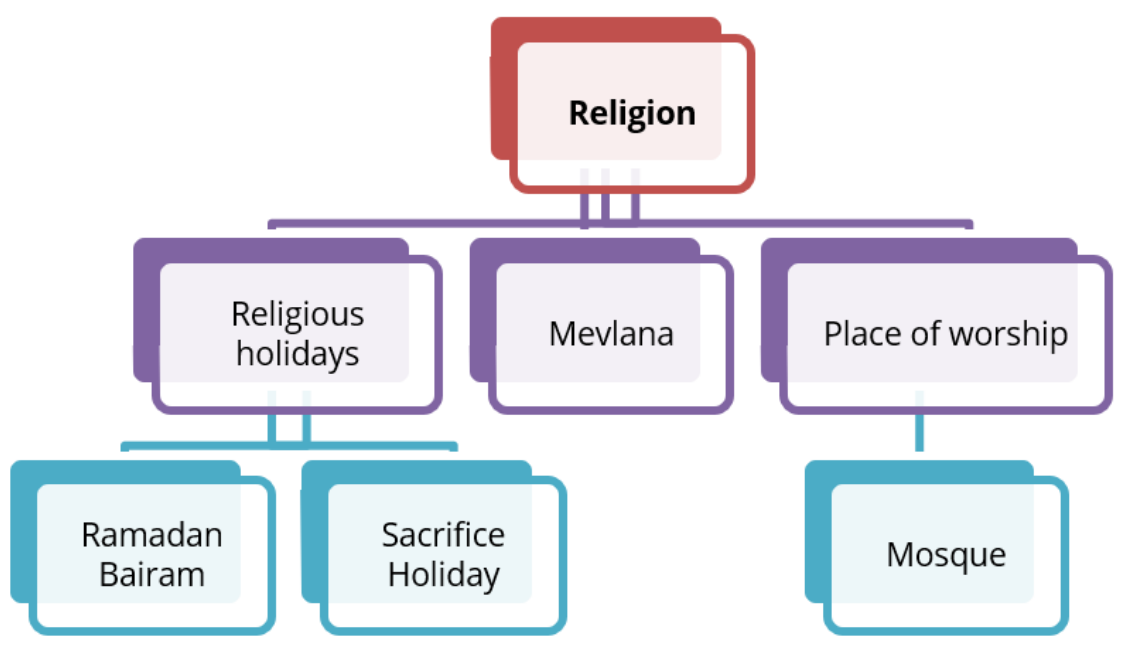

Figure 4. Religion in the drawings of third grade students 


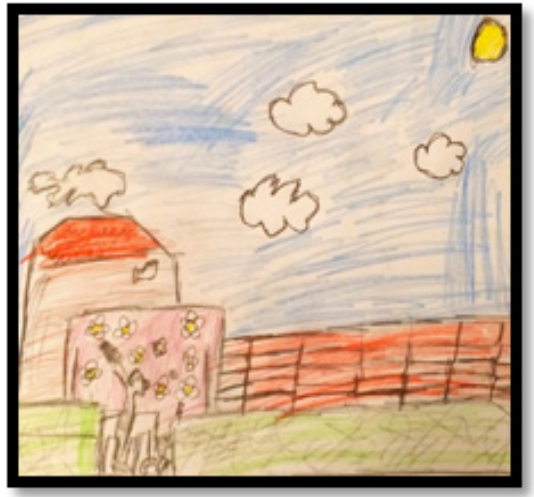

Drawing 9. Student 16

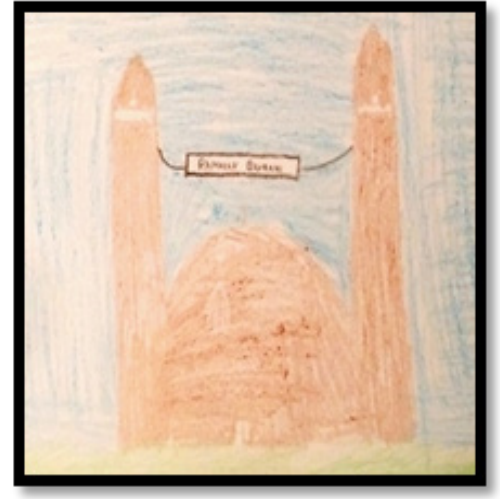

Drawing 10. Student 13

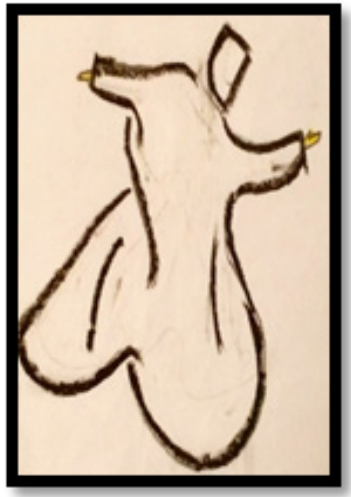

Drawing 11. Student 5

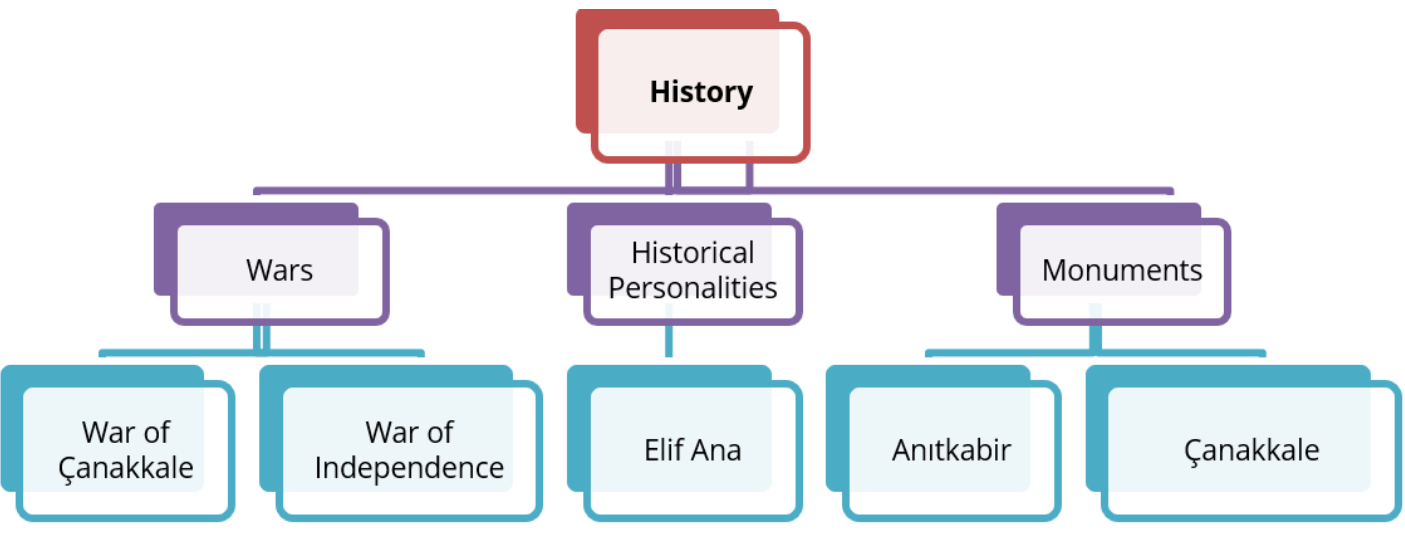

Figure 5. History in the drawings of third grade students

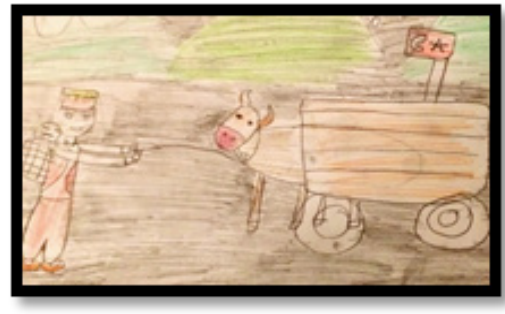

Drawing 12. Student 32 (Elif Ana)

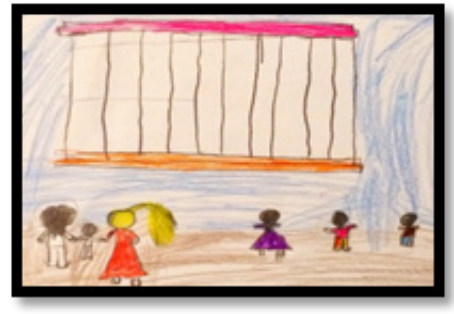

Drawing 13. Student 35 (Anıtkabir)

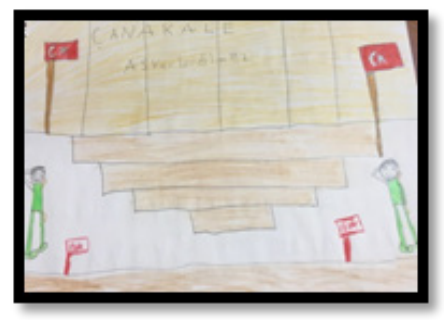

Drawing 14. Student 3 (Çanakkale)

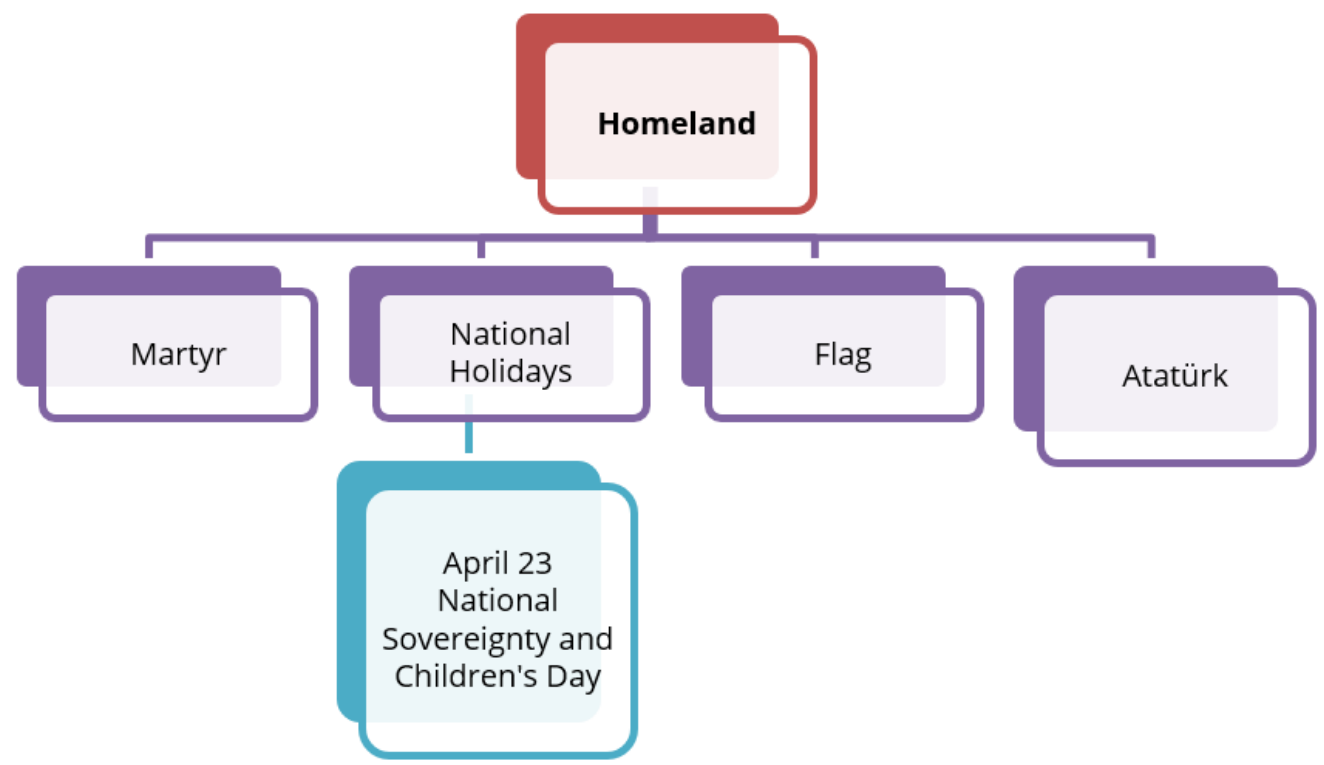

Figure 6. Homeland in the drawings of third grade students 
S16 "When it is said national and cultural value, Sacrifice Holiday came to my mind". S8 "I drew a Mosque, because we are a Muslim country." It can be said that students emphasize religious elements as national and cultural values. The drawings of students are as follows:

The history as a national and cultural values; were divided into subcategories as wars, historical personalities and monuments. The items drawn by the students are shown in Figure 5.

S32 "Our heroes came to my mind and drew Elif Ana". S35 "I drew Anıtkabir" and S3 "I drew Çanakkale and the Martyrs Monument there." The drawings of the students are as follows.

S11 "National struggle came to my mind as a national and cultural values. War of Independence is important for us" and S23 "I understand the War of Çanakkale in terms of national and cultural values." It can be said that they have emphasized our recent history as national and cultural values.

Homeland as national and cultural values were divided into as subcategories as martyr, national holidays, flag and Atatürk. The items drawn by the students are shown in figure 6.

S14 "I drew 23 April Feast.", S38 "I drew our flag." The drawings of the students are as follows.

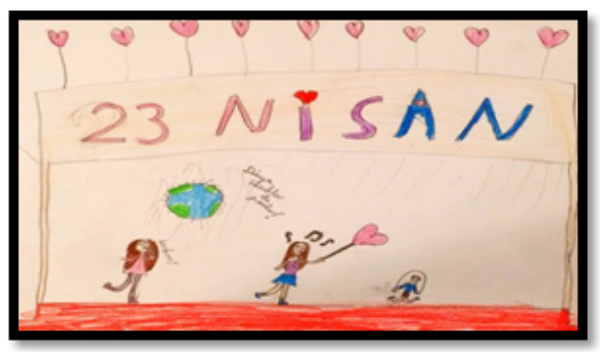

Drawing 15. Student 14

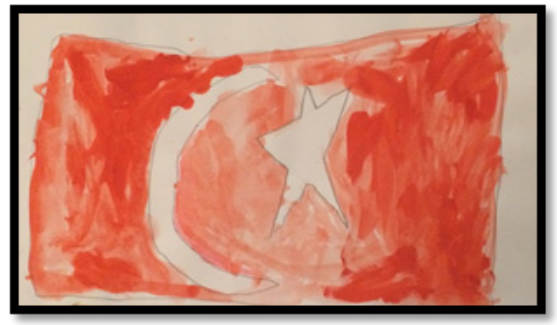

Drawing 16. Student 38
S2 "Atatürk came to my mind. He is important for us" and S35 "Martyrs in the wars came to my mind." It can be said that students emphasize our homeland as national cultural values.

The students stated the characteristics of national and cultural values in a written form. According to the opinions of students, national and cultural values are divided into sub-categories: heritage, belonging, promotion and lifestyle. Figure 7 shows the characteristics of national and cultural values.

S3 "They came us from our ancestors so it is important", S15 "It is important for us because we brought them from past to nowadays." and S22 "National Culture shows us that we are Turkish citizens and they are beauties from of Turkey. If we did not have our national culture, we would not have a culture left to us. According to this views students stated the national and cultural values as a heritage. S34 also stated that "We can show the beauties of our country to other countries and S11 stated that "It is introducing our country."

S31 "Because they show the characteristics of the region such as honey of Erzurum". S40 "Because they are values in our country so they are important" and S21 "Because they are special for us." According to these views they showed that natural and cultural values are special for our country. S8 "We are Muslims so we live like this." and S10 "Because of our values and our national culture are memories from the beauty of Turkey. If we did not have our national culture and value, we would not have any life left to us." According to these views it is emphasized that our national and cultural values are our way of life.

It can be emphasized that the students are aware of national and cultural values as it can be understood from the drawings and written expressions of the third grade students. It can also be said that students care about national and cultural values.

This situation can be explained by students' examples of national and cultural values in their school and daily life. In addition, it can be stated that students are aware of national and cultural values and their families reflect national and cultural values in their homes.

\section{Conclusion, Discussion and Suggestions}

The aim of this study, which aims to reveal the perceptions of third-grade elementary school students on national and cultural values, is the perceptions of third-year elementary school students on national and cultural values; were examined by their drawings and written opinions. $22 \mathrm{fe}-$ male and 18 male students participated in the study. The results according to findings obtained in the research are as follows.

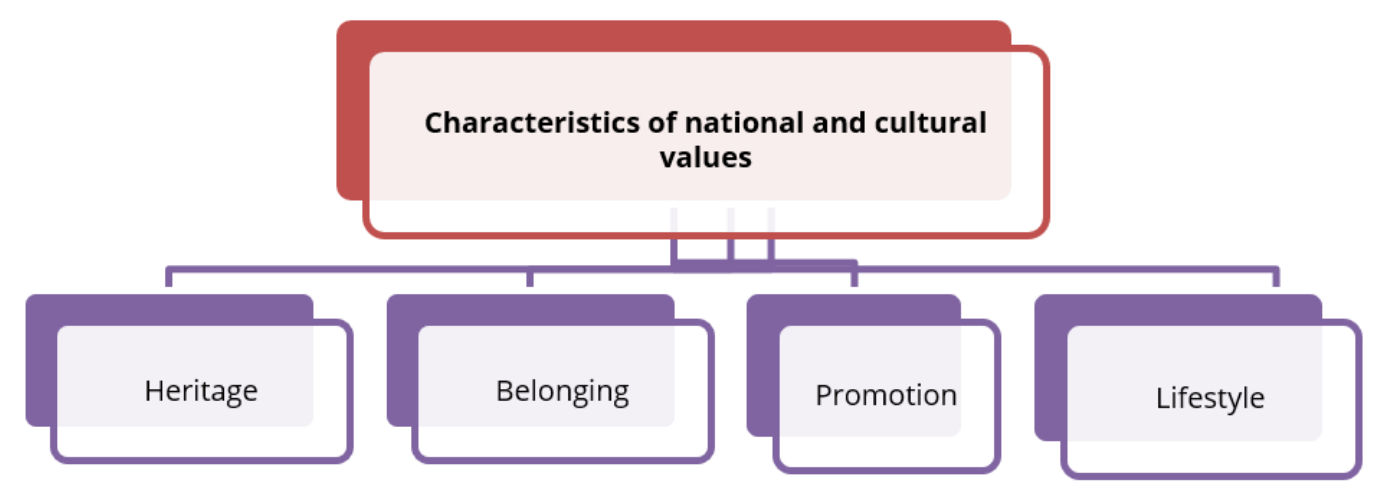

Figure 7. Characteristics of National and Cultural Values 
Students drew and expressed their perceptions about national and cultural values with their drawings and written views. While some of the students drew an object or figure as a national and cultural value, some students drew more than one figure or object related to different national and cultural values in the drawings. Some students emphasized a different national and cultural value in their written opinions and paintings. National and cultural values in the drawings and written views of the students were "customs and traditions, art, sports and language, religion, history and homeland". Students who emphasized the traditions and customs as national and cultural values, made drawings of food culture, clothes and wedding related objects or figures in their drawings and written opinions. Some students have meat roasting, rice, Turkish coffee, etc while some students draw the bride, groom and circumcision feast related to the local clothes and wedding. Some of the students who emphasize art, sports and language as national and cultural values; While drawing meerschaum and carpet weaving, some students drew our traditional sports and dances. In their separate written opinions, they emphasized the joke as national and cultural values. Some of the students who emphasized the religion as national and cultural values on their drawings and their written views were seen to drew objects and figures related to religious holidays and places of worship. Some of them drew Mevlana as a religious character. Students who emphasize history as national and cultural values; In their drawings and their written views, it was revealed that they emphasized wars, historical figures and monuments. It was determined that some of the students who emphasized the homeland as a national and cultural value drew the flag and the objects and figures related to April 23rd National Sovereignty and Children's Day. The students participating in the research showed that national and cultural values inherited from our ancestors, introduced our country, belonged to us, and reflect our lifestyle and emphasized the characteristics of national and cultural values.

In Erişti and Belet's (2010) research, the perceptions of the culture of the fifth grade students of primary schools were examined with their written expressions and paintings. As a result of the analysis of the data, some of the students explained the culture as information about the traditions and traditions of a nation, their backgrounds, and some of them explained the moral characteristics of a community, living and artistic assets, or values that a country possessed. The students expressed that cultural values are very important and should be kept alive. In addition to this, students emphasized especially the marriage ceremony, henna night, meals, dances / games, clothes, sports / horse sports, traditions / customs, soldier farewells, holidays and folk heroes. These results are harmonised to our research.

Özkartal (2009) "The effect of Dede Korkut Epic on the acquisition of national values in the course of primary art activities" aims to draw attention to the existence of Turkish epics from the cultural works and to contribute to the continuation of traditional values. In the experimental study, which was applied with pretest-posttest control group, it was observed that the student achievement and attitudes increased in the experimental group where the national values were emphasized by the drama method. With this research drama was used and we used drawing. These research both show that art could be a way of education in primary schools.

In the study of Kasa (2015) concluded that fourth grade students emphasize cultural values such as weddings, food-beverages and flags within the scope of values. These results are harmonized to our research.
Bozok (2010) "In the eighth grade visual arts lesson, the effect of our national holidays in the acquisition of national values (Sample of 29th October Republic Day and the War of Independence)" is aimed to gain national values by using stories of the Çanakkale War which describes cultural and national values through drama method. In this study, pre-test-posttest control group experimental design is used. As a result of the research, there was a significant difference in favor of the experimental group in the eighth grade visual arts class. It has been observed that student success and attitudes have increased with the method and story used in the experimental group.

Belet and Eristi (2010), aimed to explain the perceptions of the culture (the example of the multicultural Fjell elementary school in Norway). Some students' perceptions of culture in their written narratives have been highlighted by the general conditions of a country, while others reveal the cultural elements of their country such as food, dance, celebration, traditional clothing and holidays. In this study, it is seen that the ethnicity and traditional habits of the majority of the students are important in the formation of the perceptions of the majority of the students.

Schwarts (1999) mentioned values as trans-situational criteria or goals ordered by importance as guiding principles in life. Education is a part of life and has to improve values, with this study it is shown that the perceptions of students about national and cultural values.

One of the aims of education is transforming the culture to new generations. For this aim with this research, it is tried to determine third class primary students' perceptions of national and cultural values. Suggestions according to this research are:

- Quantitative research can be done. It can be studied with different level of class. The sex differences and education level of parents can be examine for national and cultural values.

- It could also study the perceptions of the students about different culture.

- Sample lesson plans can be prepared and implemented and then the effects of these practices can be investigated.

- Studies can be conducted to examine the effects of teacher-parents on students' perceptions of national culture and values.

\section{References}

Bayır-Gürdoğan, Ö. (2019). A stroy based analysis of elementary forut graders' views on respecting difference. International Electronic Journal of Elementary Education, 11(4), 403-411.

Belet, D. \& Erişti, S. D. (2009). Multicultural primary school students' ways of revealing their perception of culture in written representations and pictures. Journal of Art Education Australia, 32(2), 27-55.

Bozok, B. (2010). Illköğretim 8. sınıf görsel sanatlar dersinde millî değerlerin kazanılmasında millî bayramlarımızın etkisi (29 Ekim Cumhuriyet Bayramı ve Kurtuluş Savaşı Hikâyeleri Örneği) (Unpublished Master's Thesis). Gazi Üniversitesi, Ankara. 
Duygu, S. \& Erişti, B. (2015). Art-based educational research to generate a practice based approach. Anadolu Journal of Educational Scieneces International, 5(3), 383-401.

Eisner, E. (2006). Does arts- based research have a future?. Studies in Art Education A Journal of Issues and Research, 48(1), 9-18.

Erişti, S. D. \& Belet, D. (2010). Illköğretim öğrencilerinin yazılı anlatım ve resimlerinde kültür algıları. Elektronik Sosyal Bilimler Dergisi, 9(33), 245-264.

Finley, S. (2008). Arts-based research. In J. G. Knowless \& A. L. Cole (Eds.). Handbook of the arts in qualitative research: Perspective, methodologies, examples and issues (pp.71-81) . Thousand Oaks, CA: Sage.

Greig, A., Taylor, J., \& Mackay, T. (2007). Doing research with children. London: SAGE Publications.

Kasa, B. (2015). Illkokul dördüncü sınıf Türkçe dersinde kültürel değerler ve eğitimi: bir durum çalışması (Unpublished Doctoral Dissertation). Anadolu Üniversitesi Eğitim Bilimleri Enstitüsü, Eskişehir.

Kendrick, M. \& Mckay, R. (2004). Drawings as an alternative way of understanding young children's constructions of literacy. Journal of Early Childhood Literacy, $4(1), 109-128$.

Long, S. D. (2015). The arts in and out of school: Educational policy, provision and practice in Ireland today. International Electronic Journal of Elementary Education, 11(4), 403-411.

Mair, M., \& Kierans, C. (2007). Descriptions as data: Developing techniques to elicit descriptive materials in social research. Visual Studies, 22(2), 120-136.

McNiff, S. (2007). Art-based research. Retrieved from https://www.moz.ac.at/files/pdf/fofoe/ff_abr.pdf

MEB (2018). Hayat Bilgisi Dersi Öğretim Programı. Ankara: Meb Yayınları

Mullen, C. (2003). A self fashioned gallery of aesthetic practice. Qualitative Inquiry, 9(2), 165-182.

Özkartal, M. (2009). Ilköğretim sanat etkinlikleri dersinde Dede Korkut Destanı'nın millî değerlerin kazanılmasına etkisi (Unpublished Doctoral Dissertation). Gazi Üniversitesi, Ankara.

Paşaoğlu, S. (2009). Müzik kültüründe sözlü ve yazılı aktarım. Trakya Üniversitesi Sosyal Bilimler Dergisi, 11(2), 143-159.

Pirtle, M. J. \& Maker, J. C. (2012). A qualitative analysis of kındergarteners' open-ended drawing and storytelling oppurtunities. Zbornik Instituta za Pedagoska Istrazivanja, 44(1), 144-162.

Rolling, H. J. (2010). A paradigm analysis of arts-based research and implications for education. Studies in Art Education, 51(2), 102-114.

Schwartz, S. H. (1999). A theory of cultural values and some implications for work. Applied Psychology: An International Review, 48(I), 23-47.

Sinner, A., Leggo, C., Irwin, L. R., Gouzouasis, P. \& Grauer, K. (2006). Arts-based educational research dissertations: Reviewing the practices of new scholars. Canadian Journal of Education, 29(4), 1223-1270.
Türk Dil Kurumu (2012). Büyük Türkçe sözlük. http://www.tdk.gov.tr/index.php?option=com_gts\&arama=gts\&guid=TDK.GTS.5 2b437ed2880c6.81782799

Ulusoy, K. \& Dilmaç, B. (2012). Değerler eğitimi. Ankara: Pegem Akademi.

Yaman, H ,Taflan, S , Çolak, S . (2009). İlköğretim ikinci kademe türkçe ders kitaplarında yer alan değerler. Değerler Eğitimi Dergisi, 7(18), 107-120. Retrieved from http://dergipark.gov.tr/ded/issue/29182/312489

Yıldııım, A. \& Şimşek, H. (2011). Sosyal bilimlerde araştırma yöntemleri. Ankara: Seçkin. 